\title{
Ancestral fermented indigenous beverages from South America made from cassava (Manihot esculenta)
}

\author{
Gabriela Alejandra CHACÓN MAYORGA, Gabriela Beatriz ARIAS PALMA², Gustavo José SANDOVAL-CAÑAS (D), \\ Roberto Hugo ORDOÑEZ-ARAQUE ${ }^{3,4}$
}

\begin{abstract}
Fermented indigenous foods are of global interest, in the case of South America, fermented beverages made from cassava (Manihot esculenta) are a vital component in the daily life and diet of indigenous groups. Traditional fermentation methods promote the microbiota of beverages and consequently the generation of secondary metabolites during the spontaneous fermentation process. In addition, they improve nutritional value, ensure microbiological stability, promote flavor and aroma formation (flavor) and degrade cassava's own cyanogenic compounds. The objective of this review article is to describe the methods of artisan elaboration, the role of microorganisms on the chemical parameters of the substrates of indigenous beverages and their significance as a potential source of probiotics. The fermented cassava-based beverages studied were chicha, calugi, yakupa, caxiri, cauim, tarubá, y parakari, from Ecuador, Peru, Brazil and Guyana. A specific search was carried out in the main scientific databases using the key words: chicha, cassava, fermented beverages, Brazil, Ecuador and Peru. Articles in English and Spanish were chosen from the last 7 years to the present. It is recommended to study these beverages in depth for subsequent research and development of industrialization processes, and thus rescuing the ancestral traditions of native indigenous groups.
\end{abstract}

Keywords: food anthropology; alcoholic fermentation; lactic fermentation; cassava.

Practical Application: Some fermented beverages haven't been subject of much study, being only consumed in local market, nowadays according to the nutritional and functional properties, this beverages are required and demanded in main markets worldwide.

\section{Introduction}

Chicha, also known as native beer of South America, is a fermented beverage made from a wide variety of raw materials, applying different methods, with the indigenous people of America being the most representative group that have traditionally prepared them from corn and cassava since the knowledge of its elaboration has been transmitted from generation to generation (Caicedo \& Espinel, 2018; Grijalva-Vallejos et al., 2020; Hirsch, 2017). Generally, it is made by mixing starches or sugars with water, which are naturally fermented without microbiological or environmental control conditions, however, making the beverage by chewing the plant raw material, continues to be a common practice by indigenous groups, where the Diastase enzyme present in human saliva allows the conversion of starches to sugars (Levin et al., 2017; McGovern, 2019). The spontaneous fermentation to which the substrates are exposed allows the conversion of simple carbohydrates into secondary compounds. Additionally, fermentation can improve the bioavailability and synthesis of essential vitamins and minerals (Ramos \& Schwan, 2017; Martín \& Ramos, 2016; Todorov \& Holzapfel, 2015). With this biochemical process the nutritional quality of the beverage is improved, due to the production of biomolecules (Capozzi et al., 2012).
Chicha can have a high probiotic value, since some LAB (lactic acid bacteria) species identified in fermentation, have antagonism with pathogenic microorganisms, stimulate mucus production and improve digestibility (Freire et al., 2017a; Kandylis et al., 2016). Due to the thermal process to which the fermented beverage is subjected, cassava has a decomposition process of its toxic glycosides, which in humans cause weakness, hypothyroidism, paralysis and in severe cases, death (Shigaki, 2015).

Currently there is a social trend about the return to culinary preparations that include spontaneous food fermentations, for this reason there is a demand for functional foods, particularly non-dairy beverages (Briceño-León \& Perdomo, 2019; Garcia et al., 2019), which has caused that at an industrial level, the control of quality operations, safety of raw materials, are important aspects in the development of this type of products (Santos et al., 2019; Ordoñez-Araque \& Narváez-Aldáz, 2019).

This study aims to investigate traditional methods of elaboration, microbiology along with physicochemical parameters during the fermentation of indigenous beverages of low and high alcohol 
content made in Ecuador, Peru, Brazil and Guyana, in order to explore possible opportunities research and development.

\section{Materials and methods}

For this work, a bibliographic review of the following databases was performed: ScienceDirect, Springer, Pubmed and Google Schoolar. The descriptors used were: Chicha, cassava, fermented beverages, Brazil, Ecuador, Peru. The articles were selected according to the following inclusion criteria: a) They must be in English or Spanish; b) They must have been written in the last 7 years from 2019 (articles published in January and February 2020 were also considered); c) Articles related to fermented beverages. In the first phase 208 articles were identified, 58 that were not relevant to the research topic were excluded, 30 written in another language, 65 written before 2012. Finally, 55 papers from scientific research articles, review articles, and books were selected, book sections and encyclopedias, which were adjusted to the research criteria.

\section{Types of beverages and traditional fermentation methods}

In South America, cassava fermentation for obtaining alcoholic and non-alcoholic beverages is part of its ancestral legacy, due to its cultural, economic and social importance. The name and the form of preparation that the beverages acquire depend on the country or region that produces them (Oliveira et al., 2019).

\subsection{Ecuador and Peru}

Cassava Chicha: Is a beverage known as indigenous beer, or masato and is consumed daily by populations located in the jungle and around the Amazon River. Its preparation is a task carried out by women and consists of peeling, washing and boiling the cassava roots of sweet or bitter varieties, indistinctly until softened, the water is drained and the cassava is crushed in flat round wooden trays, the remains of cassava pieces are chewed and periodically spit into the tray (Colehour et al., 2014; Freire et al., 2016; Vallejo et al., 2013). Some indigenous groups chew edible tubers called yams (Diosocrea sp.) (Colehour et al., 2014), or red sweet potato (Ipomea batata) to sweeten and accelerate fermentation. All this is mixed and a thick mass is formed, which is placed in a clay pot called pondo (Ecuador) or pitcher (Peru and Bolivia) covered with banana leaves or with leaves of the guarumo tree (Pinto \& Abad, 2017). In some cases, old chicha is used as an inoculum to ensure fermentation. Generally, it is left to ferment for 2 to 3 days until reaching the characteristics desired by the indigenous group, which varies from: sweet, little fermented to bitter with a high level of fermentation. The alcoholic content generally varies from $2 \%$ to $5 \%, \mathrm{pH}$ from 4.0 to 4.5 , and its consistency is milky with an acidic flavor (Colehour et al., 2014).

Sankuch chicha: Within the Shuar culture (indigenous people living on the border of Ecuador and Peru), the preparation of a variant of chicha known as special chicha especial (sankuch) has been recorded. The cassava is roasted and subsequently inoculated for 5 days with reddish mushrooms (sankuch), obtained from burnt cassava stems after 4 or 5 days after harvest. The cassava decomposes and gives off pleasant smells, finally it is chewed and sweet potatoes are added to take it to a 3-day fermentation (Tsenkush \& Livia, 2013).

\subsection{Brazil}

Calugi: Is a fermented beverage with a low alcohol content, like mazamorra consistency. It is made from corn, cassava and rice by the Javaé tribe, and the inoculum used to ferment is the fluid obtained from the sweet potato chewed by the women of the tribe. It is usually consumed in the daily diet by adults and even children (Freitas et al., 2017). The cassava is peeled, washed and grated to obtain a wet mass, this mass is squeezed and is subsequently used as a fermentation substrate. Hard corn is soaked in water for 30 minutes and crushed on a wooden tray. The flour obtained is mixed with water and sifted to remove the husk. The cassava and corn dough is mixed with water and cooked for 2 hours, stirring constantly. When the porridge is cooled, the sweet potato inoculum is added, the mixture is homogenized and allowed to ferment in open aluminum containers at a temperature of approximately $30^{\circ} \mathrm{C}$ (Freire et al., 2017a; Miguel et al., 2014).

Yakupa: Beverage produced by the Juruna indigenous of Brazil, which is considered a class of cauim (pre-Hispanic alcoholic beverage of cassava or corn) refreshing but without alcohol. Yakupa is made from a dough made from cassava soaked for 2 or 3 days, known as puba. The fermented cassava is dehydrated in the sun for a few days. The dried pasta is beaten and sieved to separate the fibers, giving rise to a white liquid that goes to the fire until a cooked mash is obtained. Grated sweet potatoes are added and finally sifted to be consumed immediately when cold (Freire et al., 2014; Freitas et al., 2017).

Caxiri: It is a beverage made from cassava, corn and sweet potatoes, produced by the Juruna or Yudjá indigenous people in Brazil. Generally, it is associated with sacred rituals since it is prepared for consumption at parties and in collective work such as cutting down trees or cultivating fields (Miguel et al., 2015). Caxiri is obtained by fermenting the roots of purple cassava for two days in running water in order to soften the bark. This procedure allows the degradation of cyanogenic compounds and the formation of aromatic substances; consequently there is a softening of the roots generated by the action of lactic acid bacteria (Capredon, 2018). Subsequently, the cassava is peeled, cut into small pieces, pressed, grated and roasted. The resulting flour is then mixed with water and placed in barrels to start the fermentation process, which takes 24 to 48 hours. Caxiri is normally consumed up to 120 hours after preparation, which varies its alcohol content. (Freitas et al., 2017).

Cauim: It is a fermented alcoholic beverage produced by the Tapirapé indigenous people of the Tapiitawa tribe (indigenous community) in Brazil and represents the main food of the inhabitants. For its elaboration, various substrates can be used such as: cassava, rice and corn (Naupert, 2019). For the preparation, the cassava is immersed in running water for three or four days to soften the rind, then it is peeled, dried (in the sun), grated and ground. To start the preparation, you can mix cassava flour, rice with water, and cook until the substrate has a uniform distribution. The cooked puree obtained is cooled for 6 to 8 hours and inoculated with the juice from chewing the sweet 
potato, this juice is added little by little in the container of the beverage and then fermented in an open vessel for approximately 48 hours at room temperature (Resende et al., 2018).

Tarubá: Beverage prepared by the Sateré-Mawé tribe located between the states of Pará and Amazonas, specifically they live near the Amazon river. This is a cassava-based beverage, it is washed, peeled, ground (by pressure) and filtered to remove excess water. The resulting cassava dough is roasted for $30 \mathrm{~min}$, and is placed on a wooden tray called gareira and covered with leaves from the Trema micrantha tree (belonging to the Cannabaceae family) and from (banana). Then it is allowed to ferment for 12 days, after this time, the cassava mass is diluted in water, filtered and consumed (Adewumi, 2019; Freire et al., 2017a; Ramos et al., 2015).

Tiquira: It is a fermented and distilled beverage that is traditionally consumed in the north of Brazil, its manufacturing process consists of washing, cutting and pressing the tuber to form cakes of approximately $30 \mathrm{~cm}$ in diameter. This cake is roasted until its moisture is reduced by approximately $35 \%$, stacked in a jar and separated with cassava leaves in order to allow the bacterial flora to develop and grow. This procedure lasts between 10 and 12 days in a warm and humid climate without the presence of light, during this time the starch saccharification takes place thanks to the action of the Manila sitophila, Aspergillus niger and Penicillium sp. The mass is then diluted in water and fermented between 40 to 48 hours. Finally, a distillation is carried out to obtain a spirit with a high alcohol content (Arisseto-Bragott o et al., 2017; Savadogo et al., 2016).

\subsection{Guyana}

Parakari: Alcoholic beverage made by the Wapishana indigenous group that lives in southern Guyana, it is obtained from the fermentation of cassava through the use of amylolytic molds such as: Rhizopus sp., Mucoraceae, and Zygomycota, followed by a fermentation to obtain alcohol. This beverage is the only known example of an indigenous fermentation since the arrival of Europe in America that uses amylolytic molds, probably as a result of the domestication of the wild species of Rhizopus sp., Despite the lack of documentation, it was knows that this complex fermentation process involves at least 30 steps from harvest to consumption, in which different varieties of cassava are used (Airey \& Krause, 2017). For the elaboration, the cassava is harvested, peeled and washed to later grate it, this way the liquid is squeezed and it is left to rest during the night to eliminate toxins due to the acidification of the grated. The following day, the starch is decanted and the supernatant liquid is removed. Then, small spherical portions are molded and dried in the sun and then used as an inoculum. The grated is squeezed again and a kind of bread $2 \mathrm{~cm}$ wide and $75 \mathrm{~cm}$ in diameter is formed. It is baked to a deep brown color and then dried in the sun. At the same time, the inoculum is prepared from leaves of the T. micrantha tree that contains mycelium and spores of Rhizopus sp., that contains mycelium and spores of Parakari production.

The leaves are previously pulverized and mixed with the hot purified starch, charcoal is scattered on the ground and covered with remains of cassava shells forming a layer $2 \mathrm{~cm}$ wide, using leaves from the tropical plant Heliconia L. placing them on the remains and inoculating with the mixture of starch and T. micrantha powder. Place the loaves in pieces previously soaked in water. The process is repeated until reaching a width of $8 \mathrm{~cm}$, the loaves are covered with two layers of T. micrantha leaves, and they are left to rest for 40 to 48 hours. In some cases up to 72 hours if the cassava variety is slowly fermented to allow the growth of Rhizopus sp. Characteristic aromas and sweetness are identified to be transferred to the pondos, it is covered preventing the entry of air and pressure is released from time to time (Daly, 2020; Derka et al., 2015; Saranraj et al., 2019). The beverage can be consumed 24 hours after the fermentation, since it will be sweet and low in alcohol, if a higher alcohol content is desired, it must be fermented for up to 5 weeks.

In general, the Chicha, Cauim, and Calugi beverages are subjected to a chewing process of red sweet potato (Ipomea batatas) as a common characteristic. The product of chewing is used as an inoculum to promote fermentation and sweeten beverages. Additionally, it is identified that Tarubá and Chicha are obtained from fermentation on solid substrate, while Cauim, Calugi, Caxiri, Yakupa are obtained from fermentation in a liquid substrate. Parakari and Tiquira are made from the fermentation of cassava cakes in the presence of amylolytic fungi that give them the characteristics of each beverage (Adewumi, 2019; Freitas et al., 2017).

\section{Microorganisms associated with fermentation}

\subsection{Presence and role of microorganisms}

Fermented indigenous beverages are characterized by spontaneous or induced fermentation, with the presence of bacteria, yeasts and, in some cases, filamentous fungi. Microorganisms can be stimulated by various sources such as: saliva, water added to the substrate, the environment, utensils, and containers, in which remnants or bacteria residues from previous fermentations could be found (Yeo et al., 2019). Indigenous beverages are generally fermented by lactic acid bacteria (LAB), responsible for the acidity and decrease in $\mathrm{pH}$, the genus Lactobacillus being the predominant species, the Lactobacillus plantarum, L. brevis, L. fermentum, L. casei, L. acidophilus, L. reuteri, L. fermentum, Leuconostoc mesenteroides, Weissella confusa, W. cibaria species, have also been identified and are considered probiotic species (Freire et al., 2016; Mendoza et al., 2017). Eating food from lactic fermentation helps to have a balanced nutrition. These provide vitamins, minerals and carbohydrates, and also prevent the risk of contracting various diseases, for example, diarrhea and cirrhosis of the liver due to their probiotic properties (Nuraida, 2015).

The most frequently found yeasts belong to the genus of Saccharomyces, Candida and Pichia, thanks to them an alcoholic fermentation and formation of aromatic compounds occurs, with this the growth of LAB is stimulated and the nutritional value of beverages is improved (Piló et al., 2018). Table 1 shows the main characteristics of the ancestral indigenous beverages. 
Table 1. Fermented ancestral indigenous beverages in South America: Main characteristics.

\begin{tabular}{|c|c|c|c|c|}
\hline $\begin{array}{l}\text { Country, beverage } \\
\text { and fermentation time }\end{array}$ & Raw material & Elaboration process & Microorganisms present & Reference \\
\hline $\begin{array}{l}\text { Ecuador - Perú } \\
\text { Cassava Chicha } \\
3 \text { to } 4 \text { days }\end{array}$ & $\begin{array}{l}\text { Cassava Chicha } \\
3 \text { to } 4 \text { days }\end{array}$ & $\begin{array}{c}\text { Chewing and } \\
\text { fermentation on solid } \\
\text { substrate }\end{array}$ & $\begin{array}{l}\text { L. acidophilus, L. reuteri, L. delbrueckii, } \\
\text { L. fermentum, L. crispatus, L. mucosae, } \\
\text { Acetobacter sp., Bacillus sp. } \\
\text { Candida tropicalis, Hanseniaspora opuntiae, } \\
\text { Kodamaea ohmeri, Pichia kudriavzevii, } \\
\text { Saccharomyces cerevisiae } \\
\text { Torulaspora delbrueckii }\end{array}$ & $\begin{array}{c}\text { Colehour et al. (2014) } \\
\text { Piló et al. (2018) } \\
\text { Grijalva-Vallejos et al. } \\
\text { (2020) }\end{array}$ \\
\hline $\begin{array}{c}\text { Brasil } \\
\text { Yakupa } \\
48 \text { hours }\end{array}$ & $\begin{array}{c}\text { Cassava } \\
\text { Red sweet potato }\end{array}$ & $\begin{array}{l}\text { Fermentation in } \\
\text { liquid substrate }\end{array}$ & $\begin{array}{c}\text { Lactobacillus fermentum } \\
\text { Saccharomyces cerevisiae } \\
\text { Torulaspora delbrueckii } \\
\text { P. caribbica }\end{array}$ & Freire et al. (2014) \\
\hline $\begin{array}{l}\text { Brasil } \\
\text { Caxiri } \\
120 \text { hours }\end{array}$ & $\begin{array}{c}\text { Cassava and sweet } \\
\text { potato }\end{array}$ & $\begin{array}{l}\text { Fermentation in } \\
\text { liquid substrate }\end{array}$ & $\begin{array}{l}\text { Bacillus pumilus, B. cereus and B. subtilis } \\
\text { Sphingomonas sp and Pediococcus acidilactici } \\
\text { Saccharomyces cerevisiae, Rhodotorula } \\
\text { mucilaginosa, Pichia membranifaciens, Phica } \\
\text { guilliermondii and Cryptococcus luteolus }\end{array}$ & Miguel et al. (2015) \\
\hline $\begin{array}{c}\text { Brasil } \\
\text { Cauim } \\
48 \text { hours }\end{array}$ & $\begin{array}{l}\text { Cassava, rice and red } \\
\text { sweet potato }\end{array}$ & $\begin{array}{c}\text { Chewing and } \\
\text { fermentation on solid } \\
\text { substrate }\end{array}$ & $\begin{array}{c}\text { L. plantarum, } \\
\text { Torulaspora delbrueckii } \\
\text { L. acidophilus }\end{array}$ & Freire et al. (2017a) \\
\hline $\begin{array}{l}\text { Brasil } \\
\text { Calugi } \\
48 \text { hours }\end{array}$ & $\begin{array}{l}\text { Cassava, corn, rice } \\
\text { and red sweet potato }\end{array}$ & $\begin{array}{c}\text { Chewing and } \\
\text { fermentation on solid } \\
\text { substrate }\end{array}$ & $\begin{array}{c}\text { Corynebacterium variabile, Lactobacillus } \\
\text { paracasei, L. plantarum, L. casei, Bacillus spp. } \\
\text { (Bacillus cereus group), B. subtilis, Streptomyces } \\
\text { sp., Enterobacter cloacae, Streptococcus } \\
\text { parasanguis, Streptococcus salivarius, Weissella } \\
\text { cibaria } \\
\text { Weissella confusa }\end{array}$ & Freitas et al. (2017) \\
\hline $\begin{array}{l}\text { Brasil } \\
\text { Tarubá } \\
12 \text { days }\end{array}$ & Cassava & $\begin{array}{l}\text { Fermentation in solid } \\
\text { substrate }\end{array}$ & $\begin{array}{c}\text { Lactobacillus plantarum, } \\
\text { Lactobacillus brevis, } \\
\text { Leuconostoc mesenteroides, } \\
\text { Bacillus subtilis } \\
\text { Torulaspora delbrueckii } \\
\text { Pichia exigua, } \\
\text { Candida rugosa, T. delbrueckii, } \\
\text { Candida tropicalis, Pichia kudriavzevii, } \\
\text { Wickerhamomyces anomalus, } \\
\text { Candida ethanolica } \\
\text { Lb. plantarum, Bacillus subtilis, Bacillus } \\
\text { amyloliquefaciens, Bacillus } \\
\text { licheniformis, Bacillus sp., } \\
\text { Chitinophaga terrae }\end{array}$ & Ramos et al. (2015) \\
\hline $\begin{array}{l}\text { Brasil } \\
\text { Tiquira } \\
12 \text { days }\end{array}$ & Cassava & $\begin{array}{c}\text { Fermentation in solid } \\
\text { substrate }\end{array}$ & $\begin{array}{c}\text { Aspergillus sp } \\
\text { Penicillium sp and Neurospora, } \\
\text { Rhizopus } \mathrm{sp} \\
\text { Manila sitophila }\end{array}$ & Savadogo et al. (2016) \\
\hline $\begin{array}{c}\text { Guyana } \\
\text { Parakari } \\
112 \text { hours }\end{array}$ & Cassava & $\begin{array}{l}\text { Fermentation in solid } \\
\text { substrate }\end{array}$ & $\begin{array}{l}\text { Rhizopus } \mathrm{sp}^{1} \\
\text { Mucoraceae, } \\
\text { Zygomycota }\end{array}$ & Derka et al. (2015) \\
\hline
\end{tabular}

${ }^{1}$ Fungi with the ability to produce different types of amylase enzymes.

\section{Physico-chemical parameters}

Cassava Chicha: According to Piló et al. (2018), the final pH reaches average values of 3.94 and 4.15 , when it has had from 1 to 4 days of fermentation. In general, $\mathrm{pH}$ values can reach ranges between 4.0 and 4.5. Acidity is generated by the presence of lactic acid bacteria that increase after 48 hours. Approximately $90 \%$ of the LABs present in fermented cassava decrease the sugar content between 24 and 48 hours, and digest: glucose, gluconate, maltose, melibiose, raffinose and sucrose, while around $10 \%$ of LAB strains ferment: esculin, cellobiose, glycerol, mannitol, honeyed and rhamnose (Faria-Oliveira et al., 2015). Lactic acid is predominant at the end of fermentation, reporting values close to 4.72 and $4.58(\mathrm{~g} / \mathrm{L})$. Additionally, in the presence of the Acetobacter genus (alcohol and sugar fermenting bacteria), acetic acid can be generated, the presence of glycerol has been 
detected at values of 1.40 and $1.34(\mathrm{~g} / \mathrm{L})$, and normally ethanol at values of 2.28 and 3.15 (g/L) (Piló et al., 2018; Yépez et al., 2017).

Yakupa: In the presence of lactic acid bacteria and yeast, the initial pH is 6 and decreases to values between 4.0 and 5.0. However, compared to the presence of Torulaspora delbrueckii, the $\mathrm{pH}$ shows a decrease at 12 hours compared to LAB and other yeasts. (Resende et al., 2018). Maltose is the main carbohydrate detected $(5.13 \mathrm{~g} / \mathrm{L})$, followed by glucose $(0.016 \mathrm{~g} / \mathrm{L})$, the main organic acid is lactic acid, the presence is detected at $6 \mathrm{~h}$ of fermentation, reaching values of $4.5 \mathrm{~g} / \mathrm{L}$ at 24 hours. Lactic acid formation is attributed to the activity of L. fermentum and T. delbrueckii (Freire et al., 2015).

In the presence of $S$. cerevisiae, the organic acids found in the cassava substrate are succinic acid $(0.19 \mathrm{~g} / \mathrm{L})$ and malic acid $(0.44 \mathrm{~g} / \mathrm{L})$. In the presence of $P$. caribbica in combination with T. delbrueckii a high concentration of ethanol is produced in values between $2.1 \mathrm{~g} / \mathrm{L}$ to $2.3 \mathrm{~g} / \mathrm{L}$ respectively for each species. The combination of these yeasts and LAB generate values of $0.5 \mathrm{~g} / \mathrm{L}$ of alcohol, glycerol is produced in a greater proportion in the presence of LAB in concentrations of $0.6 \mathrm{~g} / \mathrm{L}$. Only in the presence of yeasts the registered values are $0.4 \mathrm{~g} / \mathrm{L}$ (Freire et al., 2014). The main aromatic compounds found related to the metabolism of $\mathrm{LAB}$ and yeasts except in the presence of S. cerevisiae are: 3-penten-2-ol - green vinyl; 2-butenal-3-methyl; 1,1-dimethyl-3-chloropropanol; 2-hexanol; 1,2-benzenedicarboxylic acid, bis-(2-methylpropyl) ester; dibutyl phthalate; squalene; y bis-(2-ethylhexyl) phthalate. In the presence of $S$. cerevisiae has been stablished a correlation of three volatile compounds such as 2-propenoic acid, 3-(4-methoxyphenyl)-, 2-ethylhexyl ester; acetoin; and 2-butenal-3-methyl (Freire et al., 2014, 2015; Resende et al., 2018).

Caxiri: The final $\mathrm{pH}$ of the beverage is generally 3.15 at 120 hours of fermentation, with marked acidification of the product. The carbohydrates present are maltose, glucose and fructose. The maltose reaches values of $210 \mathrm{~g} / \mathrm{L}$ at 0 hours, decreasing to values of $0.85 \mathrm{~g} / \mathrm{L}$ at 120 hours. This is probably due to the microbial activity during the fermentation of the beverage, the glucose concentration varies from 6.04 to $0.38 \mathrm{~g} / \mathrm{L}$ (Miguel et al., 2015). Like yakupa, chicha and cauim, lactic acid is the main metabolite in fermentation found, it is found in initial values of $4.59 \mathrm{~g} / \mathrm{L}$ at 0 hours of fermentation, reaching values of $27.89 \mathrm{~g} / \mathrm{L}$ at 120 hours (Faria-Oliveira et al., 2015). Acids: citric, malic, tartaric, succinic, oxalic and propionic decrease during fermentation without showing major changes in their concentrations. At $48 \mathrm{~h}$ the ethanol content reaches $70.99 \mathrm{~g} / \mathrm{L}$, at $96 \mathrm{~h}$, the ethanol content reaches values of $104.69 \mathrm{~g} / \mathrm{L}\left(13.3^{\circ} \mathrm{GL}\right)$. The presence of Saccharomyces in Caxiri is probably responsible for the formation of ethanol, while the presence of secondary compounds such as glycerol, esters, alcohol and other compounds are responsible for the aroma that characterizes the final product. (Freire et al., 2015; Freitas et al., 2017; Motlhanka et al., 2018).

Cauim: The initial $\mathrm{pH}$ is generally 5.5 and decreases to 3.5 at the end of the fermentation (after 48 hours). The carbohydrates found are maltose, glucose, fructose and sucrose. Maltose is the most abundant disaccharide, reaching values of $480 \mathrm{ug} / \mathrm{mL}$ after 24 hours of fermentation, at 48 hours it reaches $120 \mathrm{ug} / \mathrm{mL}$. Glucose is found during fermentation ranging from $170 \mathrm{ug} / \mathrm{mL}$ to $32 \mathrm{ug} / \mathrm{mL}$. After 12 hours, it reaches its maximum peak, possibly due to the activity of amylase or the metabolism of maltose of the microorganisms. Fructose and sucrose present low concentrations during the fermentation process, always in values lower than $30 \mathrm{ug} / \mathrm{mL}$ (Ramos \& Schwan, 2017; Shokoohi et al., 2015). The main organic acid present is lactic acid as a metabolite of fermentation, reaching values of $750 \mathrm{ug} / \mathrm{mL}$, the production of lactic acid increases at the end of fermentation. Another acid present is acetic acid and it occurs throughout the fermentation process due to the production of ethanol that has been produced since the beginning, with its production declining after 24 hours. Ethanol concentrations of $5 \mathrm{ug} / \mathrm{mL}$ have been estimated between 12 and 24 hours of fermentation (Faria-Oliveira et al., 2015; Freire et al., 2015; Puerari et al., 2015).

Calugi: The $\mathrm{pH}$ shows initial values of 6.20 decreasing to 4.0 , this ensures the microbiological safety of the product. An increase in protein and a decrease in the concentration of soluble starches are determined during the fermentation process, the most important sugar present is maltose, reaching maximum values of $55.70 \mathrm{~g} / \mathrm{L}$ at 12 hours of fermentation, the presence of maltose may be directly related to the conversion of starches (maltose/ glucose) by the action of the enzymatic activity of amylases on the metabolism of microorganisms. Additionally, glucose with a maximum concentration of $1.29 \mathrm{~g} / \mathrm{L}$ has been identified, as well as fructose and sucrose in low concentrations after 24 hours of fermentation (Wang et al., 2014). Regarding the ethanol content, it has a slight increase after 24 hours of fermentation, due to the heterofermentative activity of the reported LABs, such as L. plantarum, L. casei y L. paracasei.

There is also the presence of organic acids that are detected at the beginning of the fermentation, such as: citric acid, malic acid and acetic acid (metabolite of higher concentration at the beginning of the fermentation, however after $48 \mathrm{~h}$, the acid decreases considerably) (Freire et al., 2017b). Lactic acid is produced after 24 hours reaching values of $3.54 \mathrm{~g} / \mathrm{L}$ at 48 hours, during fermentation, malic, succinic, citric and propionic acids decrease, while the concentration of oxalic acid remains stable. 21 aromatic compounds have been identified, most notably furfuryl alcohol (Alonso-Gomez et al., 2016; Freitas et al., 2017).

Tarubá: Its $\mathrm{pH}$ is in a range between 4.8 to 5.8 in the first 6 days of fermentation, due to the action of Bacillus species, the beverage ends with a $\mathrm{pH}$ of approximately 4.6. Low acetic acid concentrations are detected during the 12 days of fermentation (0.2-0.5 g/kg) due to the low population of acetic acid bacteria (BAA) (Sankaranarayanan et al., 2019). In relation to carbohydrates, maltose is the compound of greater predominance during fermentation, registering initial values of $0.7 \mathrm{~g} / \mathrm{kg}$, and $4 \mathrm{~g} / \mathrm{kg}$ at 12 days. Glucose starts with $5.3 \mathrm{~g} / \mathrm{kg}$, decreasing to $2.5 \mathrm{~g} / \mathrm{kg}$, while fructose initially registers absence, to later appear at $0.3 \mathrm{~g} / \mathrm{kg}$, starting on day 8 . In general, carbohydrates show a decrease in first days of fermentation and later an increase, possibly due to the hydrolysis of the starch (Mesa et al., 2019). Additionally, organic acids such as citric, lactic, propionic, succinic, and acetic show variations in their concentrations during the 12 days of fermentation. Propionic acid concentrations are higher $(0.42-0.71 \mathrm{~g} / \mathrm{kg})$ compared to acetic, citric and succinic acid with values less than $0.43 \mathrm{~g} / \mathrm{kg}$. The ethanol concentration registers its maximum value 
after 8 days of fermentation $(0.27 \mathrm{~g} / \mathrm{kg})$ and then decreases to $0.15 \mathrm{~g} / \mathrm{kg}$ (Freire et al., 2017a; Ramos et al., 2015).

Parakari: The beverage registers similar $\mathrm{pH}$ values for different cassava varieties, whether they are slow fermented (variety: romiedar and oradowniro) or fast fermented (variety: maidanair). The $\mathrm{pH}$ reaches 5.0 values within a range of 0 to 48 hours, whose value decreases between 4.1-4.2 at 84 and 112 hours of fermentation. The initial glucose values are $7 \mathrm{~m} / \mathrm{L}$ at 24 hours, at $48 \mathrm{~h}$ it reaches the maximum glucose concentrations with values between $129 \mathrm{mg} / \mathrm{L}$ and $159 \mathrm{mg} / \mathrm{L}$ ending with values of $45 \mathrm{mg} / \mathrm{L}$ and $150 \mathrm{mg} / \mathrm{L}$, which will depend on the type of cassava used, reducing the $\mathrm{pH}$ is known to promote the rapid growth of the Rhizopus fungus (Nicolau, 2016; Sharma et al., 2016). In $\mathrm{pH}$ ranges from 4 to 5.5 it has been shown that the enzyme glucoamylase, derived from fungi, is more efficient for the production of various organic acids, allowing the formation of characteristic flavors and aromas, in addition, it is known that prolonged fermentations could promote the formation of bitter flavors in this beverage (Kaur et al., 2019; Saranraj et al., 2019).

\section{Conclusions}

The microbiota of indigenous fermented beverages is quite complex and the study of the dynamics and chemical characteristics generated in the fermentation substrates are vital for the development of new products. For this reason, new research could raise the possibility of the isolation of bacterial strains, such as $\mathrm{LAB}$, due to their protective and functional properties. Furthermore, they can be used as starter cultures in the control and optimization of the production of fermented products in order to obtain pure substances or food ingredients such as enzymes, vitamins, aroma and flavor components, pigments, proteins, trace elements, among others.

The large amount of organic acids and secondary metabolites present in beverages is of utmost importance. Subsequently, the benefit of chemical compounds in the body and in people's health could be studied in greater depth. This, with an emphasis on the production of new functional drinks, an industry that is booming today.

Despite the amount of research done, these fermented beverages have not been developed for commercial purposes. This generates the possibility of the development of new technological processes in pursuit of the industrialization of these beverages. It is possible to obtain functional drinks of high nutritional value, with probiotic potential and low alcohol content to generate new products for human consumption and the food industry.

Furthermore, it is important to rescue the customs and traditions of indigenous people so that they can be passed on to new generations and not be lost over time. Finally, it is necessary for the academy to understand and value the importance of fermented cassava beverages, as they are shared in rituals and socialization activities among indigenous people.

In conclusion, this review article is a starting point for further research of the improvement of production processes, food safety and food security of indigenous beverages prepared from cassava as raw material.

\section{References}

Adewumi, G. (2019). Health-promoting fermented foods. In L. Melton, F. Shahidi \& P. Varelis (Eds.), Encyclopedia of food chemistry (pp. 399-418). Amsterdam: Elsevier. . http://dx.doi.org/10.1016/B9780-08-100596-5.21774-5.

Airey, S., \& Krause, T. (2017). “Georgetown ain't got a tree. We got the trees". Amerindian power \& participation in Guyanas low carbon development strategy. Forests, 8(3), 51. http://dx.doi.org/10.3390/f8030051.

Alonso-Gomez, L., Niño-López, A., Romero-Garzón, A., Pineda-Gomez, P., del Real-Lopez, A., \& Rodriguez-Garcia, M. (2016). Physicochemical transformation of cassava starch during fermentation for production of sour starch in Colombia. Starch, 68(11-12), 1139-1147. http:// dx.doi.org/10.1002/star.201600059.

Arisseto-Bragotto, A., Feltes, M., \& Block, J. (2017). Food quality and safety progress in the Brazilian food and beverage industry: chemical hazards. Food Quality and Safety, 1(2), 117-129. http:// dx.doi.org/10.1093/fqsafe/fyx009.

Briceño-León, R., \& Perdomo, G. (2019). Violence against indigenous children and adolescents in Venezuela. Cadernos de Saude Publica, 35(Suppl. 3), e00084718. http://dx.doi.org/10.1590/0102-311x00084718. PMid:31433034.

Caicedo, S., \& Espinel, O. (2018). Educación indígena Kamëntzá: crianza, pensamiento, escucha. Praxis \& Saber, 9(20), 15-40. http://dx.doi. org/10.19053/22160159.v9.n20.2018.8294.

Capozzi, V., Russo, P., Dueñas, M., López, P., \& Spano, G. (2012). Lactic acid bacteria producing B-group vitamins: a great potential for functional cereals products. Applied Microbiology and Biotechnology, 96(6), 13831394. http://dx.doi.org/10.1007/s00253-012-4440-2. PMid:23093174.

Capredon, É. (2018). El encuentro de Iglesias evangélicas indígenas con Iglesias «nacionales» y sus repercusiones político-religiosas en el Alto Río Negro (Amazonas, Brasil). Boletín del Instituto Francés de Estudios Andinos, 47(3), 227-246. http://dx.doi.org/10.4000/ bifea.10095.

Colehour, A., Meadow, J., Liebert, M., Cepon-Robins, T., Gildner, T., Urlacher, S., Bohannan, B. J., Snodgrass, J. J., \& Sugiyama, L. S. (2014). Local domestication of lactic acid bacteria via cassava beer fermentation. PeerJ, 2(1), e479. http://dx.doi.org/10.7717/peerj.479. PMid:25071997.

Daly, L. (2020). The nature of sweetness: an indigenous fermentation complex in Amazonian Guyana. In K. J. Hockings \& R. Dunbar (Eds.), Alcohol and humans (pp. 130-146). Oxford: Oxford University Press. https://doi.org/10.1093/oso/9780198842460.003.0009.

Derka, T., Nieto, C., \& Svitok, M. (2015). A new species of Parakari (Ephemeroptera: Baetidae) from Guiana Highlands. Zootaxa, 4028(2), 296-300. http://dx.doi.org/10.11646/zootaxa.4028.2.9. PMid:26624312.

Faria-Oliveira, F., Diniz, R., Godoy-Santos, F., Piló, F., Mezadri, H., Castro, I., \& Brandão, R. (2015). The role of yeast and lactic acid bacteria in the production of fermented beverages in South America. In A. A. Eissa (Ed.), Food production and industry (pp. 107-135). London: IntechOpen. http://dx.doi.org/10.5772/60877.

Freire, A. L., Ramos, C. L., \& Schwan, R. F. (2015). Microbiological and chemical parameters during cassava based-substrate fermentation using potential starter cultures of lactic acid bacteria and yeast. Food Research International, 76(Pt 3), 787-795. http://dx.doi.org/10.1016/j. foodres.2015.07.041. PMid:28455064. 
Freire, A. L., Ramos, C. L., Costa Souza, P. N., Cardoso, M. G. B., \& Schwan, R. F. (2017a). Nondairy beverage produced by controlled fermentation with potential probiotic starter cultures of lactic acid bacteria and yeast. International Journal of Food Microbiology, 248, 39-46. http://dx.doi.org/10.1016/j.ijfoodmicro.2017.02.011. PMid:28242421.

Freire, A. L., Ramos, C. L., \& Schwan, R. F. (2017b). Effect of symbiotic interaction between a fructooligosaccharide and probiotic on the kinetic fermentation and chemical profile of maize blended rice beverages. Food Research International, 100(Pt 1), 698-707. http:// dx.doi.org/10.1016/j.foodres.2017.07.070. PMid:28873739.

Freire, A., Lacerda, R., Almeida, E., Duarte, W. F., \& Schwan, R. F. (2014). Study of the physicochemical parameters and spontaneous fermentation during the traditional production of yakupa, an indigenous beverage produced by Brazilian Amerindians. World Journal of Microbiology \& Biotechnology, 30(2), 567-577. http:// dx.doi.org/10.1007/s11274-013-1476-0. PMid:23996637.

Freire, A., Zapata, S., Mosquera, J., Mejia, M., \& Trueba, G. (2016). Bacteria associated with human saliva are major microbial components of Ecuadorian indigenous beers (chicha). PeerJ, 44, e1962. http:// dx.doi.org/10.7717/peerj.1962. PMid:27168974.

Freitas, R., Lacerda, C., Gonzaga, E., Farias, V., \& Pereira, E. (2017). Brazilian indigenous fermented food. In A. L. B. Penna, L. A. Nero \& S. D. Todorov (Eds.), Fermented foods of Latin America: from traditional knowledge to innovative applications (pp. 224-236). Boca Raton: CRC Press. https://doi.org/10.1201/9781315369433-14.

Garcia, M., Elias, T., Ribeiro, K., Soares, M. Jr., \& Caliari, M. (2019). Microbiological and physicochemical profiles of the sour cassava starch and bagassobtained from cassava agroindustry. Food Science and Technology, 39(4), 803-809. http://dx.doi.org/10.1590/fst.32117.

Grijalva-Vallejos, N., Aranda, A., \& Matallana, E. (2020). Evaluation of yeasts from Ecuadorian chicha by their performance as starters for alcoholic fermentations in the food industry. International Journal of Food Microbiology, 317, 108462. http://dx.doi.org/10.1016/j. ijfoodmicro.2019.108462. PMid:31794930.

Hirsch, E. (2017). Investment's rituals: "Grassroots" extractivism and the making of an indigenous gold mine in the Peruvian Andes. Geoforum, 82, 259-267. http://dx.doi.org/10.1016/j.geoforum.2016.08.012.

Kandylis, P., Pissaridi, K., Bekatorou, A., Kanellaki, M., \& Koutinas, A. (2016). Dairy and non-dairy probiotic beverages. Current Opinion in Food Science, 7, 58-63. http://dx.doi.org/10.1016/j.cofs.2015.11.012.

Kaur, P., Ghoshal, G., \& Banerjee, U. (2019). Traditional bio-preservation in beverages: fermented beverages. In A. M. Grumezescu \& A. M. Holban (Eds.), Preservatives and preservation approaches in beverages (pp. 69-113). Duxford: Woodhead Publishing. http:// dx.doi.org/10.1016/B978-0-12-816685-7.00003-3.

Levin, A., Sokal-Gutierrez, K., Hargrave, A., Funsch, E., \& Hoeft, K. (2017). Maintaining traditions: a qualitative study of early childhood caries risk and protective factors in an Indigenous community. International Journal of Environmental Research and Public Health, 14(8), 907. http://dx.doi.org/10.3390/ijerph14080907. PMid:28800116.

Martín, M., \& Ramos, S. (2016). Cocoa polyphenols in oxidative stress: potential health implications. Journal of Functional Foods, 27, 570588. http://dx.doi.org/10.1016/j.jff.2016.10.008.

McGovern, P. (2019). Alcoholic beverages as the universal medicine before synthetics. In ACS Symposium Series (Vol. 1314, pp. 111-127). http://dx.doi.org/10.1021/bk-2019-1314.ch008.

Mendoza, L., Neef, A., Vignolo, G., \& Belloch, C. (2017). Yeast diversity during the fermentation of Andean chicha: a comparison of highthroughput sequencing and culture-dependent approaches. Food
Microbiology, 67, 1-10. http://dx.doi.org/10.1016/j.fm.2017.05.007. PMid:28648286.

Mesa, E., Manjarres-Pinzon, K., \& Rodriguez-Sandoval, E. (2019). Gluten-free cheese bread from frozen dough: effect of modified cassava starch. Food Science and Technology, 39(Suppl. 2), 654-661. http://dx.doi.org/10.1590/fst.30118.

Miguel, M., Collela, C., Almeida, E., Dias, D., \& Schwan, R. F. (2015). Physicochemical and microbiological description of Caxiri a cassava and corn alcoholic beverage. International Journal of Food Science \& Technology, 50(12), 2537-2544. http://dx.doi.org/10.1111/ijfs.12921.

Miguel, S., Santos, C., Santos, M., Duarte, W., \& Freitas, R. (2014). Bacterial dynamics and chemical changes during the spontaneous production of the fermented porridge (Calugi) from cassava and corn. African Journal of Microbiological Research, 8(9), 839-849. http://dx.doi.org/10.5897/AJMR2013.6240.

Motlhanka, K., Zhou, N., \& Lebani, K. (2018). Microbial and chemical diversity of traditional non-cereal based alcoholic beverages of Sub-Saharan Africa. Beverages, 4(2), 36. http://dx.doi.org/10.3390/ beverages 4020036 .

Naupert, C. (2019). Misión y traducción en el Brasil colonial: los misioneros jesuitas como mediadores lingüísticos y culturales. CLINA: Revista Interdisciplinaria de Traducción, Interpretación y Comunicación Intercultural, 5(1), 78. http://dx.doi.org/10.14201/ clina2019516378.

Nicolau, A. (2016). Safety of fermented cassava products. In V Prakash, O. Martín-Belloso, L. Keener, S. Astley, S. Braun, H. McMahon \& H. Lelieveld (Eds.), Regulating safety of traditional and ethnic foods (pp. 319-335). Amsterdam: Academic Press. http://dx.doi.org/10.1016/ B978-0-12-800605-4.00016-5.

Nuraida, L. (2015). A review: health promoting lactic acid bacteria in traditional Indonesian fermented foods. Food Science and Human Wellness, 4(2), 47-55. http://dx.doi.org/10.1016/j.fshw.2015.06.001.

Oliveira, O., Brito, V., \& Cereda, M. (2019). Establishing a standard for handmade Brazilian cassava flour from Baixada Cuiabana (Mato Grosso, Brazil) to support its processing and sale. Food Science and Technology, 39(3), 559-566. http://dx.doi.org/10.1590/fst.30117.

Ordoñez-Araque, R., \& Narváez-Aldáz, C. (2019). Changes in the psysical-chemical composition, total polyphenols and antioxidant activity of fresh celery (Apium graveolens L.) dehydrated by hot air and by lyophilization. Agriscientia, 36(2), 57-65. http://dx.doi. org/10.31047/1668.298x.v36.n2.24036.

Piló, F., Carvajal-Barriga, E., Guamán-Burneo, M., Portero-Barahona, P., Dias, A., Freitas, L., Gomes, F. C. O., \& Rosa, C. A. (2018). Saccharomyces cerevisiae populations and other yeasts associated with indigenous beers (chicha) of Ecuador. Brazilian Journal of Microbiology, 49(4), 808-815. http://dx.doi.org/10.1016/j. bjm.2018.01.002. PMid:29705164.

Pinto, M., \& Abad, A. (2017). Valor cultural del maíz y tecnologías ancestrales en la parroquia Cayambe de Ecuador. Revista Chakiñan de Ciencias Sociales y Humanidades, 2, 47-60.

Puerari, C., Magalhães-Guedes, K. T., \& Schwan, R. F. (2015). Bacaba beverage produced by umutina Brazilian amerindians: microbiological and chemical characterization. Brazilian Journal of Microbiology, 46(4), 1207-1216. http://dx.doi.org/10.1590/S1517-838246420140964. PMid:26691483.

Ramos, C. L., \& Schwan, R. F. (2017). Technological and nutritional aspects of indigenous Latin America fermented foods. Current Opinion in Food Science, 13, 97-102. http://dx.doi.org/10.1016/j. cofs.2017.07.001. 
Ramos, C., Sousa, E., Ribeiro, J., Almeida, T., Santos, C., Abegg, M., \& Schwan, R. (2015). Microbiological and chemical characteristics of tarubá, an indigenous beverage produced from solid cassava fermentation. Food Microbiology, 49, 182-188. http://dx.doi. org/10.1016/j.fm.2015.02.005. PMid:25846929.

Resende, L. V., Pinheiro, L. K., Miguel, M. G. C. P., Ramos, C. L., Vilela, D. M., \& Schwan, R. F. (2018). Microbial community and physicochemical dynamics during the production of 'Chicha', a traditional beverage of Indigenous people of Brazil. World Journal of Microbiology \& Biotechnology, 34(3), 1-11. http://dx.doi.org/10.1007/ s11274-018-2429-4. PMid:29520720.

Sankaranarayanan, A., Amaresan, N., \& Dhanasekaran, D. (2019). Fermented food products (1st ed.). Boca Raton: CRC Press. . http:// dx.doi.org/10.1201/9780429274787.

Santos, T., Franco, C., Mischan, M., \& Leonel, M. (2019). Improvement in spray-drying technology for preparation of pregelatinized cassava starch. Food Science and Technology, 39(4), 939-946. http://dx.doi. org/10.1590/fst.10418.

Saranraj, P., Behera, S., \& Ray, R. (2019). Traditional foods from tropical root and tuber crops. In C. M. Galanakis (Ed.), Innovations in traditional foods (pp. 159-191). Duxford: Woodhead Publishing. . http://dx.doi.org/10.1016/B978-0-12-814887-7.00007-1.

Savadogo, A., Giura, F., \& Francois, T. (2016). Probiotic microorganisms involved in cassava fermentation for Gari and Attiéképroduction. Journal of Advances in Biotechnology, 6(2), 858-866. http://dx.doi. org/10.24297/jbt.v6i2.4798.

Sharma, H., Njintang, N., Singhal, R., \& Kaushal, P. (2016). Tropical roots and tubers: production, processing and technology. Chichester: John Wiley \& Sons. http://dx.doi.org/10.1002/9781118992739.

Shigaki, T. (2015). Cassava: the nature and uses. In B. Caballero, P. M. Finglas \& F. Toldrá (Eds.), Encyclopedia of food and health (pp. 687-693). Amsterdam: Academic Press. https://doi.org/10.1016/ B978-0-12-384947-2.00124-0.
Shokoohi, M., Razavi, S., Labbafi, M., Vahidinia, A., \& Gharibzahedi, S. (2015). Wheat sprout flour as an attractive substrate for the producing probiotic fermented beverages: process development and product characterisation. Quality Assurance and Safety of Crops \& Foods, 7(4), 469-475. http://dx.doi.org/10.3920/QAS2014.0402.

Todorov, S., \& Holzapfel, W. (2015). Traditional cereal fermented foods as sources of functional microorganisms. In W. H. Holzapfel (Ed.), Advances in fermented foods and beverages: improving quality, technologies and health benefits (pp. 123-153). Oxford: Woodhead Publishing. . http://dx.doi.org/10.1016/B978-1-78242-015-6.00006-2.

Tsenkush, C., \& Livia, N. (2013). Sabiduría de la Cultura Shuar de la Amazonía Ecuatoriana (1. ed.). Cuenca: Universidad de Cuenca.

Vallejo, J., Miranda, P., Flores-Félix, J., Sánchez-Juanes, F., Ageitos, J., González-Buitrago, J., Velázquez, E., \& Villa, T. G. (2013). Atypical yeasts identified as Saccharomyces cerevisiae by MALDI-TOF MS and gene sequencing are the main responsible of fermentation of chicha, a traditional beverage from Peru. Systematic and Applied Microbiology, 36(8), 560-564. http://dx.doi.org/10.1016/j. syapm.2013.09.002. PMid:24120265.

Wang, T., Chen, X., Li, L., Cao, Y., Zhao, L., Chai, Y., Zhu, Z., \& Lou, Z. (2014). Characterization of nucleotides and nucleotide sugars in Candida albicans by high performance liquid chromatography-mass spectrometry with a porous graphite carbon column. Analytical Letters, 47(2), 234-249. http://dx.doi.org/10.1080/00032719.2013.836657.

Yeo, L., Aghakhanian, F., Tan, J., Gan, H., \& Phipps, M. (2019). Health and saliva microbiomes of a semi-urbanized indigenous tribe in peninsular Malaysia. F1000 Research, 8, 150-175. http://dx.doi. org/10.12688/f1000research.17706.1. PMid:31275564.

Yépez, A., Luz, C., Meca, G., Vignolo, G., Mañes, J., \& Aznar, R. (2017). Biopreservation potential of lactic acid bacteria from Andean fermented food of vegetal origin. Food Control, 78, 393-400. http:// dx.doi.org/10.1016/j.foodcont.2017.03.009. 